\title{
CORRESPONDENCE
}

\section{SOME HISTORICAL DATA ON PARINAUD'S CONJUNCTIVITIS}

\section{To the Editor of The British Journal of Ophthalmology}

SIR,--Lest some of your younger readers may assume that the bibliography appended to Pascheff's interesting article on Parinaud's conjunctivitis and its relation to Pascheff's bacillus infectiosa necroticans (Brit. Jl. of Ophthal., January, 1924) has any pretensions to completeness it may be worth while to note that beside the ten articles mentioned, there must be at least fifty others on the subject. Parinaud's first description of the disease was published in 1886 , but the first recognition of his work in any language but French was given by the undersigned in his article in the Amer. Jl. of Ophthal., July, 1898. In this report of five cases the writer first proposed the name Parinaud's conjunctivitis on the ground that the postulate implied in Parinaud's designation (Infectious Conjunctivitis of Animal Origin) was entirely unproved. The resemblance of this disease to some cases of tuberculosis of the conjunctiva was pointed out ; as well as the occasional occurrence of giant-cells in the granulations. I mention the giant cells because Pascheff, apparently following Morax, says they do not occur in Parinaud's. Pascheff also quotes Morax to the effect that the epithelium is normal and unbroken in Parinaud's. On the contrary, Parinaud himself described conjunctival ulceration as a common symptom and it was present in all but one of my first five cases, as well as in nearly all of the ten or twelve cases which I have seen since 1898 . This by way of indicating that the line of demarcation between Pascheff's conjunctivitis necroticans infectiosa and Parinaud's conjunctivitis is hot so sharp as he seems to think. That a case with the Parinaud syndrome may be caused by one of several different germs seems highly probable'; and it seems certain that among these germs the bacillus of Pascheff must take an important rank. Historically it is of interest that the first report of this syndrome probably was that of Goldziehr who under the name Lymphadenitis Conjunctivae (Centralbl. f. Aug., p. 321, 1882) described a case four years before Parinaud's article appeared.

\section{H. GIFFORD.}

